\title{
EVALUASI KETIDAKSESUAIAN JUMLAH TEORITIS DENGAN JUMLAH AKTUAL SUSU STERIL 70 ML
}

\section{DISCREPANCY EVALUATION BETWEEN THEORITICAL AND THE ACTUAL AMOUNT OF 70 ML STERILE MILK}

\author{
Fina Uzwataniaa, Ahmad Syarbainia, Fadil Abdul Rohman ${ }^{a}$
}

aProgram Studi Tekonologi Industri Pertanian Fakultas Ilmu Pangan Halal Universitas Djuanda Bogor, Jl. Tol Ciawi No. 1, Kotak Pos 35 Ciawi, Bogor 16720.

Korespondensi: Fina Uzwatania, E-mail: fina.uzwatania@unida.ac.id

\begin{abstract}
The research was conducted in PT X. PT X is a company producing sterile milk drinks with different flavors and brands. This research objective is to evaluate the theoretical amount of discrepancies in the actual quantity of sterile milk $70 \mathrm{ml}$. The research result in the field will be compared with the document BOM (Bill of Material) as theoretical data production, then a discrepancy analyzed using Pareto charts and fish bone diagrams. Research carried out directly in the field, start from the mixing process until the process of packing. The results showed that the production loss happen in the filling and sterilization process. The percentage of the product is loss on filling process showed a higher number with a value of $79.63 \%$, while the sterilization process produces a product that is wasted by the amount of $20.37 \%$. A defective product which is obtained from the sterilization process is a defect that was not handled at the time of the inspection of products from filling machine. The results showed that the filling machine is the largest source of high product wasted during the production process. This the filling process needs to be further analyzed in order to defective products produced can be minimized.
\end{abstract}

Keywords: BOM (Bill of Material), actual output, paretto chart, fish bone diagrams

\begin{abstract}
ABSTRAK
Penelitian dilakukan di PT X. PT X merupakan perusahaan yang memproduksi minuman susu steril dengan berbagai rasa dan merek. Penelitian ini bertujuan untuk mengevaluasi ketidak sesuaian jumlah teoritis dengan jumlah aktual susu steril Milky $70 \mathrm{ml}$. Hasil penelitian di lapangan dibandingkan dengan dokumen BOM (Bill of Material) sebagai data teoritis produksi, kemudian ketidaksesuaian dianalisa menggunakan diagram pareto dan diagram fish bone. Penelitian dilakukan secara langsung di lapangan, mulai dari proses mixing sampai proses packing. Hasil penelitian menunjukan adanya produk yang terbuang pada proses filling dan proses sterilisasi. Persentase produk yang terbuang pada proses filling menunjukan jumlah yang lebih tinggi dengan nilai 79,63\%, sedangkan proses sterilisasi menghasilkan produk yang terbuang dengan jumlah 20,37\%. Produk cacat yang diperoleh dari proses sterilisasi merupakan produk cacat yang tidak tertangani pada saat inspeksi produk dari mesin filling. Hasil penelitian menunjukan bahwa mesin filling merupakan sumber terbesar tingginya produk yang terbuang selama proses produksi. Sehingga proses filling perlu dianalisa lebih lanjut agar produk cacat yang dihasilkan dapat diminimalisir.
\end{abstract}

Kata kunci : BOM (Bill of Material), output aktual, diagram pareto, diagram fish bone 


\section{PENDAHULUAN}

\section{Latar Belakang}

Ketidaksesuaian merupakan suatu hal yang sangat tidak diinginkan dalam keberlangsungan bisnis suatu perusahaan. Ketidaksesuaian memiliki banyak dampak negatif yang dapat mempengaruhi jumlah keuntungan yang akan diperoleh prusahaan. Apabila jumlah teoritis dengan jumlah aktual tidak sesuai maka nilai akhir yang diperoleh akan berbeda dengan jumlah yang seharusnya. Maka perlu dilakukan adanya penelitian mengenai ketidak sesuaian yang terjadi pada jumlah teoritis dengan jumlah aktual produk susu steril $70 \mathrm{ml}$ di PT X.

Susu merupakan susu sapi yang tidak dikurangi atau ditambahkan sesuatu apapun ke dalamnya dan diperoleh dengan pemerahan sapi-sapi sehat secara kontinyu dan sekaligus. Kebutuhan susu segar setiap tahun selalu meningkat tetapi kemampuan berproduksi sangat jauh ketinggalan, sehingga untuk memenuhi kekurangan kebutuhan susu harus selalu impor, yang berarti setiap tahun impor susu selalu meningkat yang juga dapat mengurangi devisa negara jika dibiarkan berlarut-larut (Aritonang, 2010).

Produksi susu di Indonesia belum sepenuhnya mencapai apa yang diharapkan, hal ini disebabkan antara lain oleh karena sebagian besar peternak sapi perah di Indonesia, dalam menjalankan usahanya masih bersifat tradisional, dan belum memperhatikan kebersihan baik mulai dari pemberian makanan sampai pada saat melakukan pemerahan. Adapun produksi susu nasional di Indonesia sebagian besar dihasilkan dari para peternak sapi perah tersebut dengan kepemilikan 2 - 5 ekor (Aritonang, 2010).

Jika dibandingkan dengan produksi di luar negeri masih jauh ketinggalan. Hal ini disebabkan antara lain oleh masih terbatasnya tenaga ahli yang berkecimpung di dalam bidang persusuan, kemampuan penanaman modal yang masih terbatas, belum memadainya transportasi susu cepat, mendapat saingan berat dalam pemasaran dengan susu impor terlebih dengan arus organisasi yang tidak membatasi lagi modal asing yang masuk untuk berinvestasi di bidang persusuan. Akibatnya kualitas susu di Indonesia boleh dikatakan masih rendah dan nilai jualnya pun rendah pula (Aritonang, 2010).

Objek yang dianalisa dalam penelitian ini adalah susu sterilisasi $70 \mathrm{ml}$ yang diproduksi oleh PT X. Sterilisasi adalah proses pemanasan yang bertujun untuk membunuh semua mikroba termasuk mikroba tahan panas dan pembentuk spora sehingga pada penyimpanan normal produk tetap aman untuk dikonsumsi. Suhu yang digunakan biasanya $121^{\circ} \mathrm{C}$, selama 10 menit.

Susu sterilisasi $70 \mathrm{ml}$ diproduksi melalui beberapa tahapan proses yang pada setiap prosesnya memiliki kesempatan yang sama untuk mengurangi kuantitas yang akan diperoleh ketika berakhirnya proses produksi. Semua tahapan proses tersebut terdiri dari beberapa tahapan yaitu proses mixing, proses filling, proses sterilisasi, proses labelling dan proses packing. Semua tahapan proses tersebut akan dianalisa apa saja yang menyebabkan ketidaksesuaian jumlah teoritis dengan jumlah aktual yang dihasilkan.

Penelitian ini bertujuan untuk mengevaluasi letak suatu tahapan proses produksi minuman susu steril $70 \mathrm{ml}$ yang menyebabkan ketidaksesuaian jumlah teoritis dengan jumlah aktual yang diperoleh dan mengetahui jumlah loss atau gain output produksi.

\section{METODE PENELITIAN}

\section{Teknik Pengumpulan Data}

Pengumpulan data dilakukan dengan cara analisa langsung di lapangan sehingga diperoleh data pada setiap tahapan proses produksi yang dapat mengakibatkan ketidak sesuaian jumlah output teoritis 
dengan jumlah output aktual. Data yang diperoleh kemudian dibandingkan hasilnya dengan data teoritis berupa BOM. Data yang diperoleh merupakan data yang didapat dari awal proses produksi yaitu mixing sampai tahapan akhir proses produksi yaitu packing.

\section{Desain Penelitian}

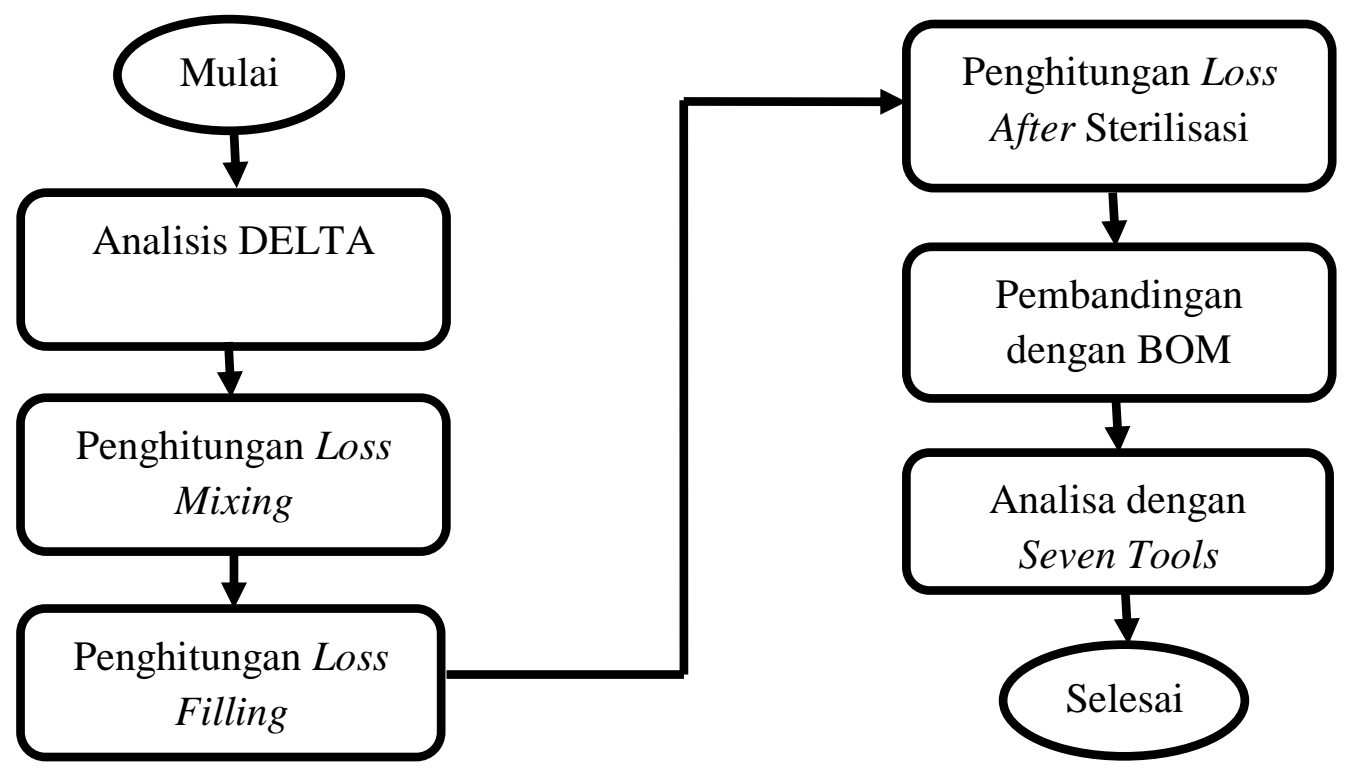

Gambar 1. Diagram Alir Desain Penelitian.

\section{Tempat dan Waktu Penelitian}

Penelitian ini dilakukan di PT X Caringin - Bogor, waktu penelitian dilaksanakan pada Oktober sampai Desember 2016.

\section{Analisis yang Digunakan}

Penghitungan untuk mengetahui jumlah ketidaksesuaian jumlah teoritis dengan jumlah aktual produksi dilakukan melalui penghitungan nilai yield produksi dengan membandingkan antara jumlah output dengan input produksi, sehingga kehilangan atau nilai loss and waste produksi dapat diperoleh dengan cara membandingkan selisih antara input dan output dibagi dengan input.

Berdasarkan data yang diperoleh, dilakukan analisis permasalahan proses pada kegiatan produksi dengan menggunakan alat bantu seven tools. Penggunaan alat bantu seven tools tidak digunakan semuanya, tetapi disesuaikan dengan kondisi permasalahan yang ada di PT X. Berdasarkan hasil analisis tersebut dapat diidentifikasi permasalahan apakah yang menjadi penyebab utama ketidak sesuaian jumlah teoritis dengan jumlah aktual di PT X.

\section{Tahap Penelitian}

Tahapan penelitian yang akan dilakukan diantaranya:

\section{Pengumpulan Data}

Data yang digunakan pada penelitian ini adalah data primer dan sekunder. Data primer diperoleh melalui pengamatan langsung di lapangan, brainstorming dan diskusi untuk mengetahui faktor-faktor penyebab terjadinya loss and waste dan mencari alternatif solusi permasalahan dalam proses pada kegiatan produksi. Wawancara dan diskusi dilakukan dengan pihak-pihak terkait sebagai narasumber yang memiliki pengalaman dan kompetensi di bidang produksi, quality dan engineering. Responden meliputi plant manager, assistant plant manager, kepala produksi, supervisor quality control dan 
kepala engineering. Sedangkan data sekunder diperoleh melalui pengumpulan dan penghitungan data laporan produksi, jumlah jam kerja, downtime mesin yang terjadi, kecepatan mesin, hasil produksi dan jumlah produk cacat. Data lain diperoleh melalui studi literatur dan informasi lain yang dapat dapat mendukung penelitian ini.

\section{Analisis Data}

Data yang telah diperoleh diolah secara langsung untuk mengetahui tahapan proses apa saja yang menyebabkan ketidak sesuaian jumlah teoritis dengan jumlah aktual. Data tersebut selanjutnya dibandingkan dengan data teoritis yang tertera pada BOM. Proses analisa data dilakukan dengan menggunakan alat bantu seven tools berupa diagram paretto dan diagram sebab akibat.

\section{HASIL DAN PEMBAHASAN}

\section{Analisa di Lapangan}

Analisa dilakukan secara langsung di lapangan pada saat proses produksi berlangsung dari mulai proses mixing sampai proses packing. Pengamatan dilakukan ketika proses pembuatan produk susu steril $70 \mathrm{ml}$ berlangsung. Pengambilan data difokuskan pada proses mixing, filling dan setelah sterilisasi. Menurut operator yang bertugas dan data perusahaan, proses tersebutlah yang biasanya menyebabkan adanya produk yang terbuang sehingga mengakibatkan terjadinya ketidak sesuaian jumlah teoritis dengan jumlah output aktual.

Kegiatan produksi di PT X perhari menghasilkan rata-rata 6 samai 7 batch produk susu steril $70 \mathrm{ml}$. Dalam 1 batch susu steril $70 \mathrm{ml}$ berukuran maksimal 5,7 ton atau sekitar 5700 liter dan dikemas ke dalam botol berukuran $70 \mathrm{ml}$ dengan mengacu pada nilai TS (total solid). Penelitian dilakukan dengan mengikuti secara langsung proses produksi dari awal hingga akhir untuk dapat mengetahui tahapan penyebab ketidak sesuaian jumlah teoritis dengan jumlah output aktual. Berdasarkan hasil pengamatan, tahapan proses mixing, filling dan sterilisasi adalah tahapan yang beresiko menjadi penyebab adanya produk yang terbuang ketika proses produksi.

Hasil pengamatan menunjukan bahwa produk yang biasa terbuang pada saat proses mixing disebabkan oleh koneksi antara pipa dengan pipa dari tanki ke mesin yang kurang sesuai. Pada saat proses filling, produk yang terbuang diakibatkan oleh produk yang tidak sesuai dengan standar atau biasa disebut dengan NG (not good) sehingga produk tersebut harus dipisahkan dan dijadikan produk reject. Sedangkan pada proses sterilisasi, produk yang terbuang jenis dan sifatnya masih sama dengan produk NG (not good) pada proses filling yaitu produk yang tidak sesuai dengan standar. Biasanya produk yang terbuang setelah proses sterilisasi selesai adalah produk NG (not good) yang tidak terambil ketika proses inspeksi di mesin filling, sehingga masih terus berjalan dan menerima perlakuan sterilisasi.

Berdasarkan hasil pengamatan yang telah dilakukan, adanya produk yang terbuang terjadi pada proses filling dan setelah proses sterilisasi. Pada saat pengamatan dilakukan, proses mixing sama sekali tidak menghasilkan produk yang terbuang. Penanganan produk yang reject atau NG (not good) pada proses filling dilakukan dengan cara mengumpulkan produk NG (not good) tersebut dan mengeluarkannya dari dalam botol lalu dimasukan ke dalam ember penampung agar dapat diketahui jumlah keseluruhan. Begitu pula dengan penanganan produk NG (not good) yang dihasilkan oleh proses sterilisasi, perlakuannya sama dengan perlakuan terhadap produk NG (not good) pada proses filling. Produk NG (not good) yang dihasilkan pada kedua peoses tersebut digabungkan untuk mengetahui total produk yang terbuang dalam 1 batch. 
Penghitungan produk NG (not good) dilakukan dengan cara mengupas isi botol lalu ditampung ke dalam ember bertujuan untuk mengetahui secara tepat berapa banyak jumlah produk yang terbuang. Bila penghitungan dilakukan dengan cara menghitung jumlah botol yang terbuang, penghitungan tidak akan akurat karena setiap botol tidak selalu berisi $70 \mathrm{ml}$ ada yang kurang dan ada yang lebih. Berdasarkan hasil penghitungan jumlah produk NG (not good) yang berasal dari proses filling dan proses sterilisasi diperoleh data sebagai berikut:

Tabel 1. Jumlah Loss Produk pada Proses Produksi.

\begin{tabular}{|c|c|c|c|c|c|c|}
\hline No & $\begin{array}{l}\text { WO (work } \\
\text { operation) }\end{array}$ & Nama Produk & $\begin{array}{c}\text { Loss } \\
\text { Mixing }\end{array}$ & $\begin{array}{l}\text { Loss After } \\
\text { Filling }\end{array}$ & $\begin{array}{l}\text { Loss after } \\
\text { Sterilisasi }\end{array}$ & Total Loss \\
\hline 1. & 16100784 & MD $70 \mathrm{ml}$ & - & $6,7 \mathrm{lt}$ & $2,8 \mathrm{lt}$ & $9,5 \mathrm{lt}$ \\
\hline 2. & 16100787 & MM $70 \mathrm{ml}$ & - & $3,7 \mathrm{lt}$ & $2,9 \mathrm{lt}$ & $6,6 \mathrm{lt}$ \\
\hline 3. & 16100816 & MD $70 \mathrm{ml}$ & - & $24,5 \mathrm{lt}$ & $2 \mathrm{lt}$ & $26,5 \mathrm{lt}$ \\
\hline 4. & 16100832 & MD $70 \mathrm{ml}$ & - & $19,4 \mathrm{lt}$ & $3,6 \mathrm{lt}$ & $23 \mathrm{lt}$ \\
\hline 5. & 16100838 & MD $70 \mathrm{ml}$ & - & $3,5 \mathrm{lt}$ & $3,7 \mathrm{lt}$ & $7,2 \mathrm{lt}$ \\
\hline 6. & 16121061 & MD $70 \mathrm{ml}$ & - & $26 \mathrm{lt}$ & $7 \mathrm{lt}$ & $33 \mathrm{lt}$ \\
\hline 7. & 16121073 & MD $70 \mathrm{ml}$ & - & $10 \mathrm{lt}$ & $2 \mathrm{lt}$ & $12 \mathrm{lt}$ \\
\hline \multicolumn{3}{|c|}{ Total Loss } & - & $93,8 \mathrm{lt}$ & $24 \mathrm{lt}$ & $117,8 \mathrm{lt}$ \\
\hline
\end{tabular}

Hasil pengamatan menunjukan bahwa selalu ada produk yang terbuang ketika proses produksi berlangsung. Data di atas menujukan tidak ada sama sekali produk yang terbuang pada saat proses mixing. Produk yang terbuang diperoleh pada proses setelah filling dan setelah proses sterilisasi berlangsung. Produk reject ini biasa disebut dengan produk NG (notgood).

Pada proses mixing tidak ditemukan sama sekali produk yang terbuang karena pada proses ini adalah proses yang paling sedikit resikonya untuk produk yang terbuang. Menurut operator yang bertugas, pada saat proses mixing berlangsung bisa saja ada produk yang terbuang yang diakibatkan oleh :

1. Operator tidak memasang karet seal di antara sambungan pipa dengan pipa sehingga ketika proses mixing berlangsung produk selalu menetes dan terbuang ketika melalui pipa yang karet seal nya tidak terpasang.

2. Karet seal yang digunakan biasanya sudah rusak sehingga karet seal yang terpasang di antara kedua sambungan pipa masih dapat menyebabkan produk menetes keluar pada saat proses mixing.

3. Pada saat perpindahan pipa ke pipa yang lain valve tanki sudah terbuka sehingga produk berkesemptan untuk keluar meski dalam jumlah yang sedikit.

Data di atas menunjukan produk yang terbuang lebih banyak pada saat setelah proses filling berlangsung. Produk yang terbuang lebih banyak diperoleh pada saat setelah proses filling berlangsung dibandingkan dengan produk yang terbuang setelah proses sterilisasi. Hal ini disebabkan oleh banyak faktor yaitu : pengaturan mesin, operator yang bertugas, jenis kemasan yang digunakan dan jenis produk yang diproses. Jenis produk NG (not good) yang dihasilan berupa :

1. Wringkle : permukaan seal kriting dikarenakan pemanasan yang berlebihan

2. Folded : bagian ujung cap steril melipat ke dalam

3. Cap steril dented : diameter mulut botol tidak sempurna atau penyok.

4. Cap steril broken : terdapat goresan pada cap steril botol. 
5. Seal sempit : seal cap steril tidak menempel pada semua permukaan mulut botol (area seal $<2.5 \mathrm{~mm}$ ).

6. Botol penyok : kondisi botol tidak sempurna karena penyok di bagian body botol.

7. Tear tergores atau sobek.

: pinggiran cap steril

8. Leak bocor karena kemasan rusak (biasanya di area seal, kondisi seal tidak sempurna).

Pada proses setelah sterilisasi masih ditemukan produk yang terbuang karena tidak masuk standar. Sebagian besar produk reject yang dihasilkan setelah proses sterilisasi berlangsung adalah produk reject yang lolos dan tidak terambil oleh petugas yang bertugas untuk mengambil produk reject setelah proses filling. Biasanya produk reject ini didominasi oleh jenis NG (not good) yang berupa seal sempit. Sehingga pada saat proses sterilisasi dengan suhu tinggi produk seal sempit tersebut terkena panas yang tinggi akibatnya produk tersebut menjadi bocor.

\section{Output Produksi Hasil Pengamatan}

Pada satu siklus produksi susu steril $70 \mathrm{ml}$ berlangsung volume per batch jumlahnya sebesar 5700 liter. Secara teori dalam satu siklus produksi akan menghasilkan susu steril $70 \mathrm{ml}$ sebanyak 81.428 Pcs. Maka jika jumlah produk yang dihasilkan tidak sesuai dengan jumlah teoritis tersebut dapat disimpulkan adanya ketidak sesuaian pada saat proses produksi berlangsung.

Tabel 2. Jumlah output akhir Produksi.

\begin{tabular}{ccccc}
\hline No & $\begin{array}{c}\text { WO (work } \\
\text { operation) }\end{array}$ & Nama Produk & $\begin{array}{c}\text { Rata-rata } \\
\text { Volume }\end{array}$ & Output Akhir (Pcs) \\
\hline 1. & 16100784 & MD 70 ml & $70,31 \mathrm{ml}$ & 77082 \\
2. & 16100787 & MM 70 ml & $70,72 \mathrm{ml}$ & 79071 \\
3. & 16100816 & MD 70 ml & $70,44 \mathrm{ml}$ & 78660 \\
4. & 16100832 & MD 70 ml & $71,16 \mathrm{ml}$ & 78540 \\
5. & 16100838 & MD 70 ml & $72,03 \mathrm{ml}$ & 75180 \\
6. & 16121061 & MD 70 ml & $69,49 \mathrm{ml}$ & 78660 \\
7. & 16121073 & MD 70 ml & $69,34 \mathrm{ml}$ & 78820 \\
\hline
\end{tabular}

Data di atas semuanya menunjukan hasil output produksi yang kurang dari jumlah teoritis yang direncanakan. Artinya pada setiap siklus produksi selalu ada produk yang terbuang ketika proses berlangsung. Data penelitian di atas menunjukan tidak adanya gain atau hasil output produksi yang melebihi jumlah teoritis yang direncanakan. Data di atas menunjukan nilai rata-rata volume yang dihasilkan mesin filling sangat beragam, tidak sama rata $70 \mathrm{ml}$ seperti yang direncanakan. Hal ini disebabkan oleh pengaturan volume pada mesin filling yang pengaturannya masih dilakukan secara manual bersasarkan pengalaman para operator. Tidak adanya standar pengaturan volume mesin filling menjadi penyebab utama nilai rata-rata volume yang dihasilkan tidak sama pada setiap batch produksi.

\section{Perbandingan Output dengan BOM}

Untuk memulai suatu proses produksi perlu direncanakan seperti apa dan jumlah yang diinginkan berapa banyak. Secara teori perencanaan pembuatan produk Susu steril $70 \mathrm{ml}$ tercantum pada BOM (Bill of Material) yang telah dibuat oleh perusahaan. BOM ini dibuat guna menjadi acuan untuk hasil akhir yang diperoleh setelah proses produksi selesai. BOM dibuat oleh departemen Research and Development yang didalamnya berisi tentang seluruh informasi rencana pemakaian bahan. BOM ini merupakan dokumen rahasia 
perusahaan yang tidak dapat di berkepentingan. Berikut data BOM yang perlihatkan kepada orang yang tidak diperlukan untuk penelitian ini.

Tabel 3. BOM (Bill of Material) Produk Susu steril $70 \mathrm{ml}$.

\begin{tabular}{cccccc}
\hline No & Nama Produk & $\begin{array}{c}\text { TS (total } \\
\text { solid) }\end{array}$ & Hasil Akhir & $\begin{array}{c}\text { Volume } \\
\text { Produk }\end{array}$ & Batch Size \\
\hline 1. & Susu steril Dark $70 \mathrm{ml}$ & $15,0 \%$ & 81.439 & $70 \mathrm{ml}$ & $5700 \mathrm{lt}$ \\
2. & Susu steril Malt $70 \mathrm{ml}$ & $14,8 \%$ & 81.629 & $70 \mathrm{ml}$ & $5700 \mathrm{lt}$ \\
3. & Susu steril Swiss $70 \mathrm{ml}$ & $14,5 \%$ & 81.405 & $70 \mathrm{ml}$ & $5700 \mathrm{lt}$ \\
4. & Susu steril Stroberi $70 \mathrm{ml}$ & $14,0 \%$ & 71.269 & $70 \mathrm{ml}$ & $5000 \mathrm{lt}$ \\
\hline
\end{tabular}

Berdasarkan data di atas setiap varian produk Susu steril $70 \mathrm{ml}$ memiliki nilai TS (total solid) yang berbeda-beda. Hasil akhir jumlahnya berbeda-beda terutama susu steril Stroberi $70 \mathrm{ml}$ karena jumlah batch size nya paling kecil yaitu 5000 liter. Sedangkan standar volume yang tertera di dalam BOM adalah $70 \mathrm{ml}$.
Namun di lapangan volume ini memiliki nilai toleransi sebesar $0,50 \mathrm{ml}$. Jadi minimal volumenya adalah $69,50 \mathrm{ml}$ dan maksimalnya adalah $70,50 \mathrm{ml}$. Apabila nilai rata-rata volume tidak memenuhi batas minimal dan melebihi batas maksimal maka ada hal yang tidak sesuai ketika proses filling berlangsung.

Tabel 4. Persentase Yield dan Loss Produksi

\begin{tabular}{|c|c|c|c|c|c|c|c|c|}
\hline No & $\begin{array}{c}\text { WO (work } \\
\text { operation } \\
\text { ) }\end{array}$ & Nama Produk & $\begin{array}{c}\text { Rata- } \\
\text { rata } \\
\text { Volume }\end{array}$ & $\begin{array}{c}\text { Jumlah } \\
\text { Output } \\
(P C S)\end{array}$ & $\begin{array}{c}\text { Output } \\
\text { Teoritis } \\
(P c S)\end{array}$ & $\begin{array}{c}\text { Selisih } \\
(P c S)\end{array}$ & $\begin{array}{c}\% \\
\text { Yield }\end{array}$ & $\begin{array}{c}\% \\
\text { Loss }\end{array}$ \\
\hline 1. & $\begin{array}{c}1610078 \\
4\end{array}$ & MD $70 \mathrm{ml}$ & $\begin{array}{c}70,31 \\
\mathrm{ml}\end{array}$ & 77082 & 81.439 & 4357 & $\begin{array}{c}94,6 \\
5\end{array}$ & 5,35 \\
\hline 069 & $\begin{array}{c}1610078 \\
7\end{array}$ & MM $70 \mathrm{ml}$ & $\begin{array}{c}70,72 \\
\mathrm{ml}\end{array}$ & 79071 & 81.629 & 2558 & $\begin{array}{c}96,8 \\
7\end{array}$ & 3,13 \\
\hline 3. & $\begin{array}{c}1610081 \\
6\end{array}$ & $\mathrm{MD} 70 \mathrm{ml}$ & $\begin{array}{c}70,44 \\
\mathrm{ml}\end{array}$ & 78660 & 81.439 & 2779 & $\begin{array}{c}96,5 \\
9\end{array}$ & 3,41 \\
\hline 4. & $\begin{array}{c}1610083 \\
2\end{array}$ & $\mathrm{MD} 70 \mathrm{ml}$ & $\begin{array}{c}71,16 \\
\mathrm{ml}\end{array}$ & 78540 & 81.439 & 2899 & $\begin{array}{c}96,4 \\
4\end{array}$ & 3,55 \\
\hline 5. & $\begin{array}{c}1610083 \\
8\end{array}$ & $\mathrm{MD} 70 \mathrm{ml}$ & $\begin{array}{c}72,03 \\
\mathrm{ml}\end{array}$ & 75180 & 81.439 & 6259 & $\begin{array}{c}92,3 \\
1\end{array}$ & 7,68 \\
\hline 6. & $\begin{array}{c}1612106 \\
1\end{array}$ & MD $70 \mathrm{ml}$ & $\begin{array}{c}69,49 \\
\mathrm{ml}\end{array}$ & 78660 & 81.439 & 2779 & $\begin{array}{c}96,5 \\
8\end{array}$ & 3,13 \\
\hline 7. & $\begin{array}{c}1612107 \\
3\end{array}$ & MD $70 \mathrm{ml}$ & $\begin{array}{c}69,34 \\
\mathrm{ml}\end{array}$ & 78820 & 81.439 & 2619 & $\begin{array}{c}96,7 \\
8\end{array}$ & 3,21 \\
\hline
\end{tabular}

$$
\begin{aligned}
\% \text { Yield } & =\frac{\text { Jumlah Output }}{\text { output Teoritis }} \\
\% \text { Loss } & =\frac{\text { Selisih }}{\text { output Teoritis }}
\end{aligned}
$$

Data di atas merupakan data hasil pengamatan secara langsung ketika proses produksi susu steril $70 \mathrm{ml}$ berlangsung. Data yang diperoleh adalah Susu steril 70 ml varian Dark dan Malt. Hasil penelitian menunjukan nilai rata-rata volume yang berbeda antara batch satu dengan yang lainnya. Pada data yang diperoleh nilai volume yang memenuhi standar hanya data pertama dan data ke tiga, karena data 
tersebut memenuhi kriteria minimal volume $69,50 \mathrm{ml}$ dan maksimal volume $70,50 \mathrm{ml}$. Nilai rata-rata volume yang dihasilkan per botol sangat berpengaruh terhadap jumlah hasil akhir yang diperoleh. Apabila nilai rata-rata volume terlalu besar maka berpotensi mengurangi jumlah akhir yang akan diperoleh. Sebaliknya jika nilai rata-rata volume terlalu kecil kurang dari nilai minimum volume produk maka berpotensi terhadap hasil akhir yang diperoleh melebihi jumlah teoritis yang ditetapkan.

Hasil akhir yang diperoleh pada data di atas menunjukan jumlah yang lebih kecil dari jumlah teoritis yang telah ditentukan pada BOM. Hal tersebut menunjukan selalu ada produk yang terbuang pada saat proses produksi berlangsung. Produk yang terbuang di dominasi oleh proses filling dan setelah proses sterilisasi sedangkan pada proses mixing sama sekali tidak ditemukan produk yang terbuang selama proses pengamatan berlangsung. Produk yang terbuang karena reject atau cacat menjadi penyabab berkurangnya hasil akhir yang diperoleh.

Data di atas menunjukan nilai yield tertinggi diperoleh pada data ke dua sebesar 96,87\% yang memiliki jumlah output akhir terbesar. Selisih terbesar antara jumlah teoritis dengan jumlah output terdapat pada data ke lima dengan selisih sebesar 6259. Jumlah loss atau kehilangan tertinggi terdapat pada data ke lima dengan nilai loss sebesar 7,68\%.

\section{Analisa Diagram Pareto}

Dari data hasil pengamatan jumlah loss produk yang terbuang pada saat proses produksi berlangsung dibuat ke dalam bentuk diagram. Hasil perhitungan diagram pareto dari persen kumulatif dapat dilihat hasilnya pada Tabel 5.

Tabel 5. Hasil Perhitungan Diagram Pareto dari Persen Kumulatif

\begin{tabular}{llccc}
\hline No & Sumber Loss & Jumlah Loss & $\%$ & $\%$ Kumulatif \\
\hline 1. & After Filling & $93,8 \mathrm{lt}$ & $79,63 \%$ & 79,63 \\
2. & After Sterilisasi & $24 \mathrm{lt}$ & $20,37 \%$ & 100 \\
& Total & $117,8 \mathrm{lt}$ & 100 & \\
\hline
\end{tabular}

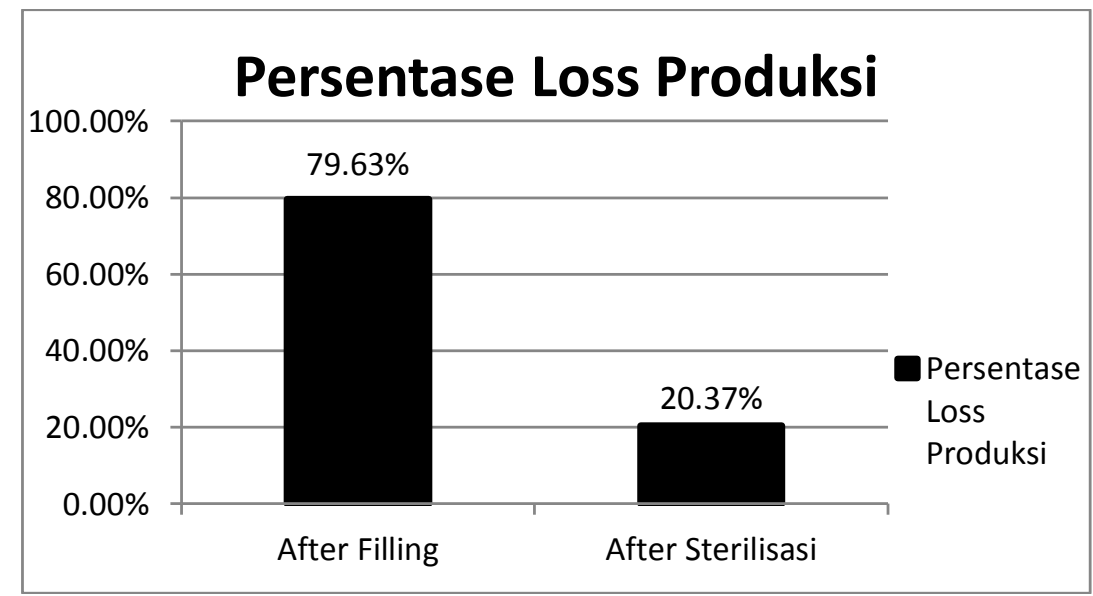

Gambar 2. Diagram Pareto Persentase Loss Produksi.

Dari hasil pengamatan selama proses produksi berlangsung dapat disimpulkan bahwa tahapan proses produksi yang menyebabkan tingkat kehilangan produk yang paling tinggi ialah setelah proses filling berlangsung. Tingkat kehilangan produk yang lain terjadi setelah perlakuan sterilisasi dilakukan. Perbedaan loss yang 
dihasilkan begitu signifikan yaitu 79,63\% loss setelah proses filling dan $20,37 \%$ loss yang dihasilkan setelah proses sterilisasi. Data tersebut disajikan melalui diagram pareto pada Gambar 2.

\section{Analisa Diagram Sebab Akibat}

Tingkat kehilangan produk paling tinggi berasal dari produk reject yang dihasilkan setelah proses filling berlangsung. Meskipun ada jumlah produk yang hilang setelah proses sterilisasi dilakukan namun jumlahnya jauh lebih kecil bila dibandingkan dengan produk cacat yang dibuang setelah proses filling. Produk cacat setelah proses sterilisasi bisa saja lebih banyak jumlahnya dibandingkan dengan produk cacat yang diakibatkan oleh proses filling. Namun biasanya itu terjadi ketika pada saat proses sterilisasi mesin mengalami kendala yang sangat berat sehingga merusak kualitas produk yang disterilisasi dalam jumlah besar. Oleh sebab itu perlu dilakukan penelitian lebih lanjut terhadap proses filling yang berlangsung ketika proses pembuatan produk Susu steril $70 \mathrm{ml}$. Untuk mengetahui tingginya tingkat produk cacat yang dihasilkan setelah proses filling, maka digunakan alat bantu fish bone diagram atau diagram sebab akibat. Penyusunan dilakukan melalui brainstorming dengan pihak yang bertugas. Pada diagram ini dirumuskan faktor-faktor yang berpotensi menjadi penyebab masalah.

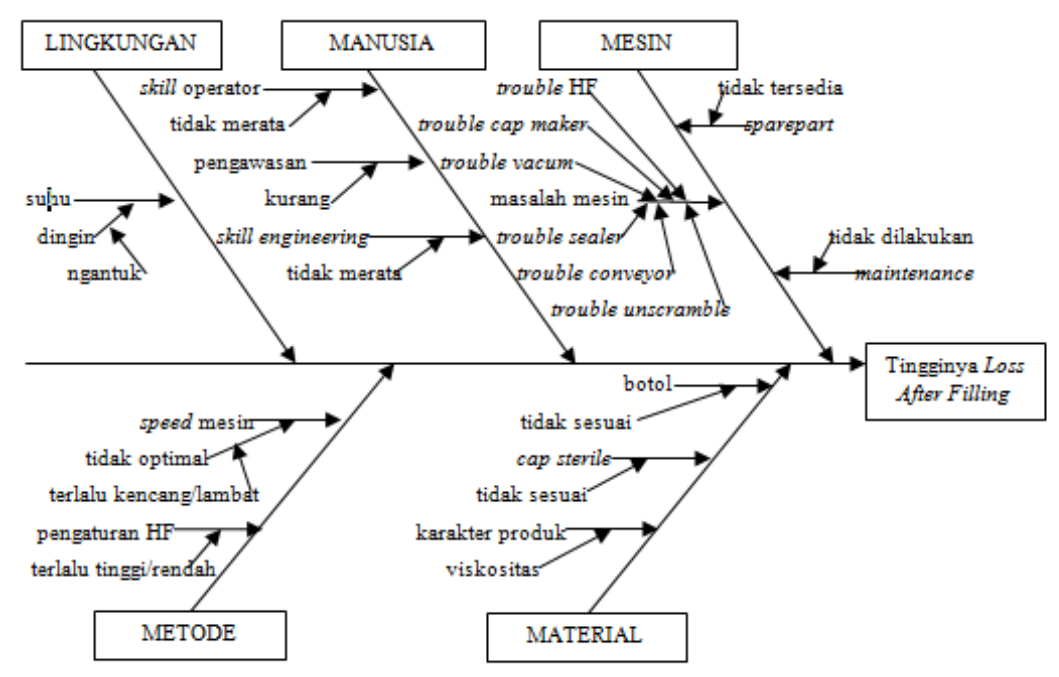

Gambar 3. Diagram fish bone Tingginya Loss Proses Filling.

Berikut disajikan hasil analisanya :

a. Mesin

Mesin merupakan faktor yang paling berpengaruh terhadap tingginya jumlah produk yang tidak memenuhi standar. Permasalahan banyak sekali terjadi ketika mesin dijalankan secara terusmenerus. Permasalahan yang terjadi penyebab tingginya produk cacat pada proses filling diantaranya : trouble $\mathrm{HF}$, trouble cap maker, trouble vacum, trouble sealer, trouble conveyor dan trouble unscramble. Itulah penyebab munculnya produk cacat yang tidak layak untuk dipasarkan. Berbagai macam trouble tersebut terjadi karena komponen-komponen mesin yang mulai rusak dan tidak adanya perawatan atau maintenance mesin secara berkala. Akibatnya mesin sering mengalami masalah dan tingkat produk cacat pun semakin tinggi.

b. Manusia

Manusia disini bertugas untuk mengoperasikan mesin agar bekerja optimal sesuai dengan yang diharapkan. Manusia merupakan faktor penentu baik atau buruk performa mesin ketika 
dijalankan. Penyebab tingginya produk yang terbuang ketika proses filling adalah kemampuan manusia sebagai operator tidak merata, pengawasan yang kurang dan kemampuan tim engineering untuk mengatasi masalah mesin tidak seragam. Sebaiknya dilakukan validasi setiap operator filling agar dapat dengan mudah menyeragamkan kemampuan mereka mengoperasikan mesin dengan baik dan benar sesuai ketentuan. Pengawasanpun harus lebih ditingkatkan karena mesin yang lancar ketika beroperasi selalu mengalami kendala meski dalam rentan waktu yang sedikit. Begitu juga dengan personil engineering, perlu adanya penyeragaman pemahaman dan kemampuan terhadap mengatasi masalah yang terdapat pada mesin.

c. Material

Material yang digunakan sangat berpengaruh terhadap kinerja mesin yang beroperasi. Setiap mesin didesain secara khusus untuk beroperasi berdasarkan jenis dan ukuran material yang telah ditentukan. Material yang digunakan pada saat proses filling berlangsung yaitu botol susu plastik, cap steril dan produk yang akan diproses. Kendala akan terjadi ketika material botol dan cap steril yang akan digunakan jenis dan dimensinya tidak sesuai dengan persyaratan yang diinginkan oleh mesin yang akan beroperasi. Produk yang akan diproses pun akan menjadi penyebab masalah

.g terjadi apabila produk tersebut kositasnya tidak sesuai.

d. Metode

Metode yang tepat akan membuahkan hasil yang memuaskan. Penggunaan metode yang paling baik untuk mengoperasikan mesin filling akan meminimalisir jumlah produk cacat yang akan terbuang karena tidak sesuai standar. Metode yang tepat untuk digunakan pada saat proses filling adalah kecepatan mesin dan nilai $\mathrm{HF}$ yang optimal, tidak terlalu tinggi ataupun terlalu rendah. Kecepatan mesin yang terlalu tinggi menyebabkan banyak terjadinya volume kurang ditandai dengan botol yang tidak terisi secara sempurna. Sebaliknya jika kecepatan terlalu rendah maka volume atau isi botol akan terlalu banyak. Namun apabila pengaturan HF terlalu tinggi maka yang terjadi adalah produk cacat berupa over heat sehingga seal antara cap steril dan mulut botol terlalu menerima panas yang berlebih akibatnya warna cap steril berubah dan produk akan bocor. Sebaliknya jika pengaturan HF rendah, maka kualitas seal akan lemah dan berdampak terhadap banyaknya produk cacat berupa seal sempit area sealnya kurang dari 2,5 mm.

e. Lingkungan

Lingkungan sangat berpengaruh terhadap kenyamanan manusia dan mesin ketika bekerja ataupun beroperasi. Pada saat proses filling produk Susu steril $70 \mathrm{ml}$, ruangan filling dinilai bersuhu terlalu rendah yaitu 16 derajat celcius. Akibatnya operator yang bertugas kurang bersemangat karena merasa kedinginan. Hal ini berakibat terhadap turunnya semangat operator yang bertugas karena mereka sering merasakan kantuk yang berlebih.

\section{KESIMPULAN}

Berdasarkan data hasil pengamatan dapat disimpulkan bahwa ketidak sesuaian jumlah teoritis dengan jumlah output aktual diakibatkan oleh adanya produk reject pada proses filling dan setelah proses sterilisasi. Pada saat pengamatan berlangsung, proses mixing sama sekali tidak menghasilkan produk yang terbuang ketika proses berlangsung. Produk reject yang terbuang sebagian besar berasal dari proses filling dengan nilai $79,63 \%$. Sisanya produk reject yang terbuang berasal dari proses sterilisasi 
dengan nilai sebesar 20,37\%. Hasil pengamatan menunjukan nilai volume mesin filling yang dihasilkan sangat beragam. Tidak adanya standar pengaturan volume mesin filling menjadi penyebab utama nilai rata-rata volume yang dihasilkan tidak sama pada setiap batch produksi.

Dapat disimpulkan bahwa proses filling adalah proses yang paling besar pengaruhnya terhadap tingginya produk reject yang terbuang pada proses produksi. Tingginga produk reject pada proses filling diakibatkan oleh faktor yang mempengaruhi kelancaran mesin filling ketika beroperasi. Faktor tersebut adalah mesin, manusia, material, metode dan lingkungan. Semua faktor tersebut belum dilakukan perbaikan secara optimal sehingga produk reject yang diperoleh masih tinggi.

\section{DAFTAR PUSTAKA}

Aritonang, N Salam. 2010. Susu dan Teknologi. Sawagati Press. Jl Sukapura No. 15 Cirebon.

Gaspersz, V. 1998. Statistikal Process Control, Penerapan Teknik-teknik dalam Manajemen Bisnis Total. PT Gramdia Utama. Jakarta.

Ishikawa, K. 1989. Teknik Pengendalian Mutu. Mediatama Sarana Perkasa. Jakarta.

Kusrini Ina. 2016. Kamus Kesehatan. Copyright $^{\complement} 2016$ Kamus Kesehatan.

Lukmanulhakim. 2013. Mempelajari Proses Produksi dan Teknologi Pengemasan pada Minuman Susu Cair di PT X. Ciherang Pondok, Caringin. Bogor.

Marimin. 2004. Pengambilan Produksi di Industri Pangan. Modul Kuliah. Institut Pertanian Bogor, Bogor.

Muhandri, T. 2004. Perencanaan Produksi di Industri Pangan. Modul Kuliah. Institut Pertanian Bogor, Bogor

Nuraini, Latifah. 2012. Stabilizer dan Emulsifier. Teknologi Pengolahan
Hasil Pertanian. Universitas Gajah Mada. Yogyakarta.

Tim HACCP. 2016. Buku Pedoman Pelaksanaan GMP. PT X..Jl Mayjen HRE Sukma Km. 15 No. 3 Ciherang Pondok, Caringin Bogor.

[SNI]. Standar Nasional Indonesia. 1992. No. 01-2897-1992. Cara Uji Cemaran Mikroba. Jakarta: Badan Standarisasi Nasional.

Soejodono RR. 2004. Bahan Kuliah Mikrobiologi Pangan. Bogor: Program Pasca Sarjana Kesehatan Masyarakat Veteriner. Institut Pertanian Bogor.

[USDEC]. United State Dairy Export Council. 2006. Skim Milk Powder. Arlington USA. US Dairy Export Council. 